\title{
PENINGKATAN KESEHATAN BALITA MELALUI POS GERAKAN PENANGGULANGAN STUNTING (POS GENTING) DENGAN METODE EDUKASI DI DESA PAJARAN, PETERONGAN
}

\section{THE INCREASING OF HEALTH OF TODDLERS THROUGH "POS GENTING" WITH EDUCATIONAL METHOD IN PAJARAN VILLAGE, PETERONGAN}

\author{
I'in Noviana ${ }^{1)}$ Ariesta Ikhsanul Putri' ${ }^{2)}$ \\ ${ }^{1,2}$ Prodi Sarjana Keperawatan, STIKES Pemkab Jombang \\ Email:iinnoviana22@gmail.com
}

\begin{abstract}
ABSTRAK
Stunting merupakan permasalahan kesehatan yang sering terjadi di berbagai negara, tak terkecuali Indonesia. Stunting merupakan gangguan nutrisi yang menyebabkan proses pertumbuhan dan perkembangan Balita menjadi terhambat. Beberapa hal tersebut beresiko besar terhadap masa depan Balita kedepannya, dikhawatirkan Balita akan menjadi tidak produktif. Stunting sendiri merupakan masalah yang penyebabnya sangat kompleks, yaitu dari faktor Ibu atau calon Ibu, faktor genetik, konginental, atau balita tersebut sendiri dan faktor sosial serta lingkungan. Program POS Gerakan Penanggulangan Stunting ini memiliki beberapa metode guna menangani Stunting yaitu, Edukasi guna meningkatkan pengetahuan Ibu atau Orang Tua balita mengenai stunting serta upaya pencegahannya. Mengobati serta mengembalikan status nutrisi Balita dengan Stunting. Berdasarkan hasil implementasi program dalam waktu intensif 2 bulan didapatkan bahwa metode edukasi tersebut mampu mengurangi angka kejadian Stunting, memperbaiki status nutrisi Balita dengan Stunting serta dapat memberikan Ibu atau Orang Tua Balita pengetahuan lebih mengenai Stunting dan cara untuk mengatasinya. Hal tersebut sesuai dengan penyebab Stunting bahwa perbaikan status nutrisi Balita Stunting memang penting namun perbaikan pola asuh dan peningkatan pengetahuan Ibu atau Orang Tua mengenai Stunting juga tidak kalah penting dalam upaya pencegahan Stunting. Berdasarkan hasil observasi setelah pelaksanaan program dengan pemberian edukasi yang tepat sehingga metode penanganan Stunting yang telah dilaksanakan oleh Tim mampu mengurangi angka kejadian Stunting.
\end{abstract}

Kata Kunci : Stunting, Balita, Orang Tua, POS Genting.

\section{ABSTRACT}

Stunting is a health problem that occurs in various countries, including Indonesia. Stunting is a nutritional disorder that causes the growth and development of toddlers. Some of these things have a big risk to the future of Toddlers, it is feared that Toddlers will become unproductive. Stunting itself is a problem whose causes are very complex, which is maternal factors or prospective mothers, genetic, congenital, or toddler factors themselves and social environmental factors. The Stunting Prevention Movement POS program (POS Genting) has a method to deal with stunting, which is education to increase the knowledge of mothers or parents of toddlers about stunting Based on the results of the implementation of the program in an intensive 2 months was found that this method were able to reduce the incidence of stunting, improve the nutritional status of toddlers with stunting and can provide mothers or parents of toddlers with more knowledge about stunting and ways to overcome them. This is in accordance with the causes of Stunting that improving the nutritional status of Stunting of Toddlers is indeed important, but improving parenting patterns and increasing knowledge of Mothers or Parents about Stunting are no less important in preventing stunting. Based on the results of observations after the implementation of the program by carrying out educational method of and method that has been implemented by the Team of the Stunting is able to reduce the incidence of Stunting.

Keywords : Stunting, Children under five, parents, POS Genting

\section{PENDAHULUAN}

Stunting adalah suatu kondisi dimana balita memiliki panjang atau tinggi badan yang kurang jika dibandingkan dengan umur. Kondisi ini diukur dengan panjang atau tinggi badan yang lebih dari minus dua, standar deviasi median pertumbuhan anak oleh WHO. Balita stunting termasuk masalah gizi kronik yang disebabkan oleh banyak faktor seperti kondisi sosial ekonomi, gizi ibu saat hamil, kesakitan pada bayi, dan kurangnya 
asupan gizi pada bayi. Balita stunting di masa yang akan datang akan mengalami kesulitan dalam mencapai perkembangan fisik kognitif yang optimal. Berdasarkan data Riset Kesehatan Dasar (Riskesdes) Tahun 2018 diperoleh fakta bahwa bayi usia dibawah lima tahun (balita) yang terindetifikasi stunting di Kabupaten Jombang yakni mencapai 17,90\%. Sedangkan data terbaru berdasarkan bulan timbang yang dilaksanakan dibulan Februari 2019 oleh Dinas Kesehatan bersama Kader Kesehatan yang teridentifikasi stunting di Kabupaten Jombang saat ini yang merupakan generasi bangsa terancam kurang memiliki daya saing dimasa depan

Penyebab stunting paling besar di Jombang, khususnya didaerah Dusun Pajaran kurang lebih 5\% dengan jumlah 90 balita,13 balita yang mengalami stunting dari beberapa faktor diantaranya sosial dan ekonomi, mengingat pendapatan dari masyarakat Kabupaten Jombang yang rendah. Hal ini yang menyebabkan banyak masyarakat khususnya balita (dibawah 5 tahun) yang mengalami stunting akibat dari pemenuhan nutrisi yang kurang. POS Gerakan Penanggulangan Stunting (POS GENTING), merupakan solusi permasalahan yang ada. Tujuan dari POS Gerakan Penanggulangan Stunting ini adalah untuk meminimalisir tingkat stunting di daerah Jombang. Upaya pertama yang telah kita lakukan adalah dengan melakukan survey kepada balita yang ada di desa pajaran, Tim Genting melakukan pengukuran tinggi badan dan timbang berat badan pada balita. Langkah kedua adalah dengan melakukan upaya edukasi kepada para orangtua mengenai stunting.

Stunting merupakan suatu kondisi permasalahan kurang gizi kronis yang disebabkan kurangnya asupan gizi dalam waktu yang relative lama akibat dari tidak seimbangnya pemberian makanan dengan kebutuhan gizi balita (Kementrian Kesehatan Republik Indonesia, 2016). Sasaran pada program ini adalah 13 keluarga yang ada di Dusun Pajaran yang mempunyai balita stunting. Pada saat musim pandemi seperti ini, memberikan dampak yang cukup serius pada masyarakat Indonesia, terutama untuk 13 keluarga balita stunting yang ada di Dusun Pajaran. Dampak yang dialami keluarga balita stunting di dusun Pajaran akibat pandemi ini adalah di sektor ekonomi dan Kesehatan. Dalam segi ekonomi, masa pandemi ini membuat kondisi ekonomi mengalami penurunan yang cukup drastis bergitu pula dengan keluarga di Dusun Pajaran. Di saat pandemi ini pendapatan masyarakat semakin menurun, angka pengangguran di Dusun ini pun naik. Dengan kondisi ekonomi keluarga yang rendah, membuat pemenuhan gizi balita di Dusun Pajaran ini pun rendah. Kondisi ekonomi yang rendah membuat daya beli masyarakat khususnya orangtua untuk memenuhi kebutuhan gizi anaknya pun terganggu. Akibatnya, kebutuhan gizi yang diperlukan oleh balita seperti protein, karbohidrat, kalsium, zat besi dan zinc tidak dapat terpenuhi sehingga angka stunting pada balita meningkat.

\section{METODE}

Pada kegiatan POS Gerakan Penanggulangan Stunting ini terdiri dari metode pencegahan dan penanganan Stunting, yang mana metode tersebut memiliki peranan dan fungsi masing-masing yaitu :

a. Preventif Preventif merupakan tindakan pencegahan yang dapat dilakukan sebelum terjadinya permasalahan Stunting. Tindakan ini dilakukan dengan melakukan promosi serta pemberian informasi tambahan mengenai topik seputar stunting. Metode preventif merupakan suatu kegiatan pencegahan terhadap suatu masalah kesehatan atau penyakit. Oleh karena itu sangat penting untuk dilakukan guna meningkatkan pengetahuan ibu atau orang tua sebagai lingkup pertama balita dalam kehidupannya. Dengan meningkatnya kemampuan ibu atau orang tua dapat melakukan upaya maintenance guna memastikan status nutrisi serta pertumbuhan dan perkembangan balita tidak mengalami hambatan.

b. Edukasi Upaya edukasi atau pemberian informasi mengenai stunting ditujukan dalam hal peningkatan pengetahuan ibu atau orang tua mengenai stunting. Pendekatan melalui metode edukatif ini memberikan ibu atau orang tua gambaran umum dan spesifik mengenai stunting, 
memunculkan minat serta semangat ibu atau orang tua dalam mengetahui kondisi status nutrisi, pertumbuhan serta perkembangan balita.

c. Konseling, Pemberian konseling diberikan saat merupakan pemberian informasi mengenai Stunting ditujukan dalam hal peningkatan pengetahuan ibu atau orang tua mengenai stunting Pendekatan melalui metode edukatif ini akan memberikan ibu atau orang tua gambaran umum dan spesifik mengenai stunting, memunculkan minat serta semangat ibu atau orang tua dalam mengetahui kondisi status nutrisi, pertumbuhan serta perkembangan balita. Tahapan tersebut adalah :

- Skrining : mencari dan menetapkan judul balita Stunting pada suatu lokasi, menggunakan metode standart kesehatan nasional.

- Edukasi : memberikan penyuluhan mengenai stunting kepada ibu atau orang tua dengan balita stunting.

- Konseling : mencari kendala yang menjadi penyebab terjadinya stunting pada setiap balita serta permasalahan lain dari balita stunting secara lebih spesifik.

- Pemberian nutrisi tambahan : pemberian nutrisi tambahan sesuai dengan gizi atau usia serta kebutuhannya.

\section{HASIL DAN PEMBAHASAN}

Adapun pokok materi yang kami sampaikan yaitu : a. Penentuan jumlah balita stunting berdasarkan klarifikasinya

b. Menjelaskan tentang stunting dan pengaruhnya terhadap pertumbuhan dan perkembangan balita

c. Indikator stunting

d. Klarifikasi stunting

e. Gizi seimbang balita.

Pada bulan kedua dan ketiga, kami melaksanakan bimbingan konseling yang mana pada langkah kedua ini diketahui :

- Jumlah balita penderita stunting berdasarkan klarifikasinya (tingkat keparahannya)

- Keluhan dan kendala yang dialami oleh masing-masing balita penderita stunting

- Pemberian Makanan Tambahan (PMT) Upaya rehabilitatif yang tepat pada masing-masing balita penderita stunting adalah pemenuhan gizi yang seimbang.

- Pemenuhan gizi serta nutrisi sesuai yang tertera pada Kartu Genting
Metode pengembangan yang dilakasanakan merupakan sebuah rangkaian tahapan yang disusun secara sistematis, berikut adalah pelaksanaan yang berjalan :

1. Identifikasi masalah berdasarkan data Riset Kesehatan Dasar (Riskesdes) Kabupaten Jombang tahun 2018

2. Penetapan lokasi sasaran berdasarkan angka persebaran pengidap stunting dari data Riset Kesehatan Dasar (Riskesdes) Kabupaten Jombang tahun 2018

3. Observasi lokasi sasaran meliputi, masyarakat, balita, pekerjaan seharihari orang tua balita, dan pola makan balita

4. Perencanaan program meliputi, perencanaan susunan acara, perencanaan target, dan perencanaan sistematika pelaksanaan program

5. Perizinan penyuluhan dari pihak terkait

6. Penentuan jumlah balita stunting

7. Penyusunan materi penyuluhan

8. Pelaksanaan program meliputi penyuluhan, bimbingan konseling, dan pelaksanaan upaya kuratif dan rehabilitatif

9. Evaluasi pelaksanaan program meliputi, laporan kemajuan dan laporan evaluasi program POS Genting

- Peningkatan pengetahuan ibu balita

stunting melalui Buku Pedoman Program Penanggulangan Stunting Mengingat penyebab utama stunting di wilayah tersebut mayoritas disebabkan oleh faktor sosial-ekonomi. Kami mencoba memodifikasi bahan PTM dengan yang mudah dijangkau oleh masyarakat. Sebagai contoh Ikan kakap yang mungkin sulit dicari dan harganya juga relatif mahal, kami menggantikan ikan kakap tersebut dengan ikan lele. Karena ikan lele tersebut mudah dicari dan juga harganya relatif terjangkau. Ikan lele juga memiliki kandungan protein yang tak kalah dengan ikan kakap yaitu sebanyak 18 gram, sedangkan kandungan protein ikan kakap yaitu sebanyak 20 gram.

Hasil dari program penanggulangan stunting ini diukur dari:

- Meningkatnya pengetahuan dan wawasan yang luas bagi orang tua

- Meningkatnya gizi pada balita

- Meningkatnya derajat kesehatan balita

- Meningkatnya semangat orang tua dalam memberikan asupan makanan pada balita.

- Meningkatnya nafsu makan pada balita. 
Program POS Gerakan Penanggulangan Stunting tidak hanya berhenti sampai disini namun terdapat potensi berkelanjutan yang dilakukan dan mampu mencegah adanya stunting terhadap balita. Beberapa tahapan yang dilakukan yaitu : 1) Orang tua balita melaksanakan program secara mandiri dengan bantuan Buku Pedoman pelaksanaan Program 2) Pemantauan balita oleh kader posyandu.

Dokumentasi hasil kegiatan:
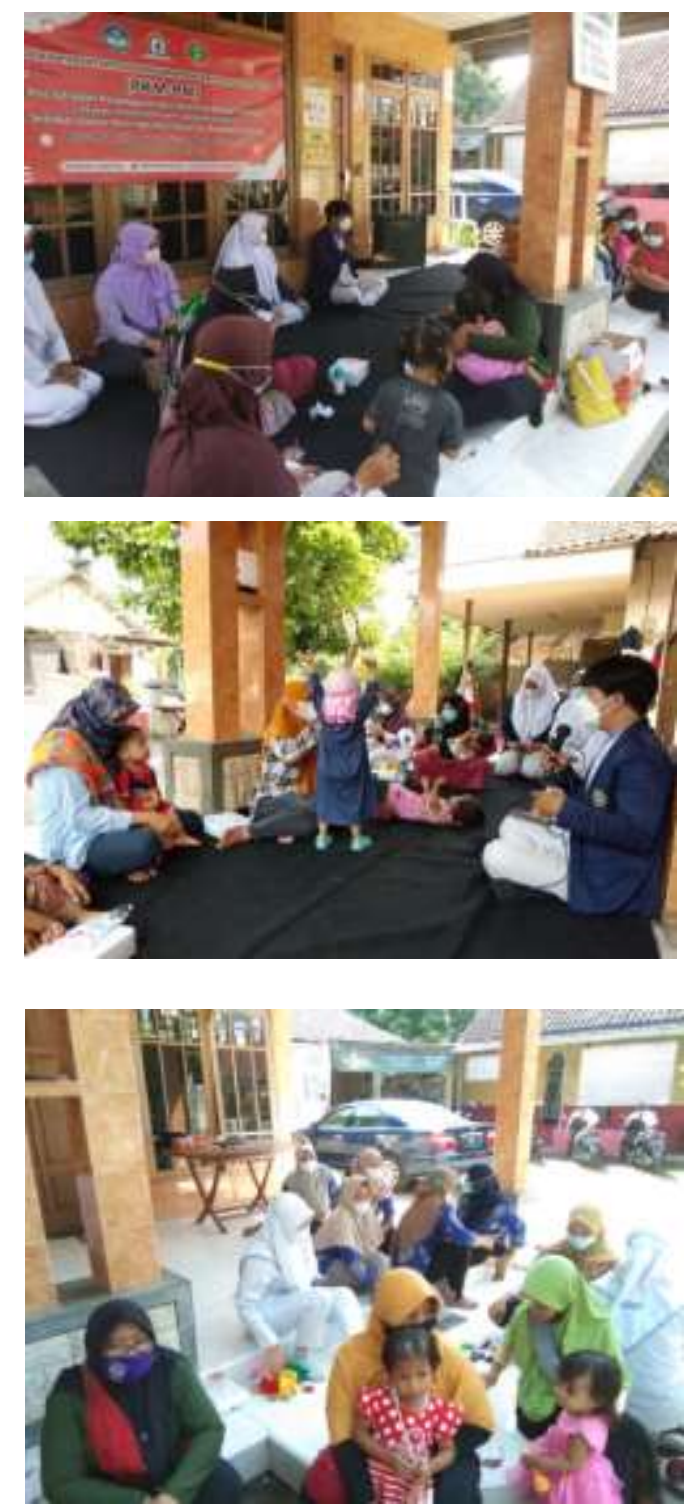

\section{KESIMPULAN}

Berdasarkan hasil yang diperoleh dari program pengabdian masyarakat ini dapat disimpulkan:

1. Jumlah balita yang ada di dusun Pajaran yang mengalami penurunan derajat kesehatan sejumlah 13 anak

2. Peningkatan kesehatan Balita yang diukur dari berat badan dan tinggi badan balita
3. Pengetahuan orang tua tentang kesehatan balita meningkat

4. Angka penurunan dari Stunting di desa Pajaran

\section{SARAN}

Saran yang dapat disimpulkan dari pelaksanaan program peningkatan kesehatan Balita adalaha:

1. Diharapkan adanya keberlanjutan program yang dilakukan oleh desa dengan pihak terkait

2. Diharapkan adanya dukungan dari masyarakat untuk bersama - sama meningkatkan kesehatan Balita

\section{DAFTAR PUSTAKA}

Afifa, I., 2019. Kinerja Kader dalam Pencegahan Stunting: Peran Lama Kerja sebagai Kader, Pengetahuan dan Motivasi. Jurnal Kedokteran Brawijaya, 30(4).

Rosmalina Y, Luciasari E, Aditianti A, Ernawati F, 2018. Upaya Pencegahan Dan Penanggulangan Batita Stunting: Systematic Review. Gizi Indonesia, 41(1):1-14.

Sri Astuti, G. M. d. S. C., 2018. Gerakan Pencegahan Stunting Melalui Pemberdayaan Masyarakat Kecamatan Jatinagor Kabupaten Sumedang. Jurnal Aplikasi Ipteks untuk Masyarakat,7(3):185-188.

asri, N., Sididi, M., \& Sartika. (2021). Faktor yang Berhubungan dengan Kejadian Stunting pada Balita (24-36 Bulan). Window of Public Health Journal, 416425.

https://doi.org/10.33096/woph.v1i5.98

Indonesia, K. K. R., 2018. 1 dari 3 Balita Indonesia Derita Stunting. 09

April. Rahmadhita, K. (2020). Permasalahan Stunting dan Pencegahannya. Jurnal Ilmiah Kesehatan Sandi Husada, 11(1), 225-229.

https://doi.org/10.35816/jiskh.v11i1.253

RI, K. K., 2018. Situasi Balita Pendek (Stunting) di Indonesia. Cegah Stunting, Itu Penting. WHO, 2014. 